\title{
Evaluation of ecto and endo parasitic fauna of Schizothorax plagiostomus inhabitants of river Swat, Khyber PakhtunKhwa, Pakistan
}

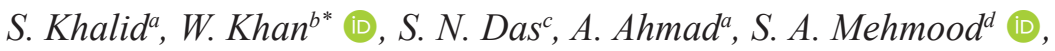 \\ W. A. Pahanwar (D), S. Ahmed d (D), M. Kamalf (D), M. Waqas ${ }^{\text {, R. M. Waqas }}$, \\ H. Ul Hassan ${ }^{\text {(D), S. Zahoor }}$ and A. Maqbool

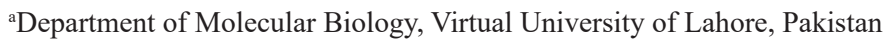 \\ ${ }^{b}$ Department of Zoology, University of Malakand, Lower Dir, Pakistan \\ 'Department of Zoology, University of Sindh, Jamshoro, Pakistan \\ ${ }^{\mathrm{d}}$ Department of Zoology, Hazara University, Mansehra, Pakistan

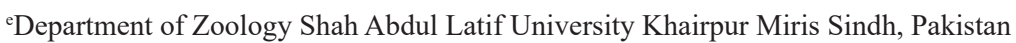 \\ fDepartment of Zoology, University of Karachi, Karachi, Pakistan \\ gDepartment of Zoology, Marine Resource Collection Centre, University of Karachi, Pakistan

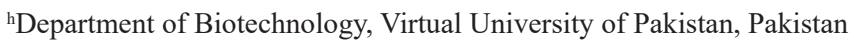 \\ *e-mail: walikhan.pk@gmail.com
}

Received: April 3, 2019 - Accepted: August 26, 2019 - Distributed: February 28, 2021

(With 1 figure)

\begin{abstract}
Fish is consumed as a rich and cheaper source of white meat and proteins all over the world. Fish farming is the leading source of income generation throughout the world. The present research study was conducted with aims to investigate the ecto and endo parasitic fauna of S. plagiostomus (snow trout) in River Swat. A total of 96 fish samples were collected on monthly basis from July-2018 to February-2019, from upper, middle and lower reaches. Fish samples were collected with the help of cast net, hand net and fishing rods. Local fishermen and experts help were also sought out for fish collection. 61 out of 96 fishes were found infected by helminth parasites. The total prevalence and intensity of $63.54 \%$ and 2.90 was observed respectively during data analysis. Highest monthly prevalence of $83.33 \%$ was recorded during July and August, while lowest prevalence of $33.33 \%$ was noted during February. Five species of helminths parasites were detected from S. plagiostomus, of which two were trematodes (Rhabdochona shizothoracis and Rhabdochona species), one species of Monogenia (Diplozoon paraddoxum), one species of Cestodes (Nippotaenia species), and one species of Acanthocephalan (Neoechynorhynchus devdevi). Highest parasite wise prevalence, intensity and relative density of $21.87 \%, 4.09$ and 0.895 was noted for $R$. schizothoracis while the lowest prevalence, intensity and relative density of $4.16 \%, 1.25$ and 0.052 was noted for N. devdevi. Highest infection of $76.08 \%$ was observed in adults host while lowest, $40 \%$ infestation rate was observed in young fish samples. $73.68 \%$ prevalence was observed in female hosts while only $56.90 \%$ prevalence was observed in male individuals. Higher infection (83.33\%) was noticed during summer season, while lowest infection $(44.44 \%)$ was observed during winter season. Similarly $71.79 \%$ fishes were found infected that were collected from lower reaches of the River Swat than the fish samples collected from upper reaches (52\%).
\end{abstract}

Keywords: intensity, prevalence, helminth parasites, river Swat.

\section{Avaliação da fauna ecto e endoparasitária de Schizothorax plagiostomus habitantes do rio Swat, Khyber Pakhtunkhwa, Paquistão}

\section{Resumo}

O peixe é consumido mundialmente por ser uma fonte rica e barata de carne branca e proteínas. A piscicultura é a principal fonte de geração de renda em todo o mundo. O presente estudo foi conduzido com o objetivo de investigar a fauna ecto e endoparasitária de S. plagiostomus (truta da neve) no rio Swat. Foram coletadas mensalmente 96 amostras de peixes, no período de julho de 2018 a fevereiro de 2019, nos trechos alto, médio e baixo com auxílio de redes de arrasto, redes de mão e varas de pesca. Pescadores locais e especialistas também ajudaram na coleta de peixes. Dos 96 peixes encontrados, 61 estavam infectados por parasitas helmintos. A prevalência de $63,54 \%$ e a intensidade total de 2,90 foram observadas durante a análise dos dados. A maior prevalência mensal de 83,33\% foi registrada nos meses de julho e agosto, enquanto a menor, de 33,33\%, em fevereiro. Cinco espécies de parasitas helmintos foram 
detectadas de S. plagiostomus, dos quais dois eram trematódeos (espécies Rhabdochona shizothoracis e Rhabdochona), uma espécie de monogenia (Diplozoon paradoxum), uma espécie de cestóideos (espécie Nippotaenia) e uma espécie de acantocéfalo (Neoechynorhynchus devdevi). As maiores prevalências de parasitas $(21,87 \%)$, intensidade $(4,09)$ e densidade relativa $(0,895)$ foram observadas em R. schizothoracis, enquanto as menores prevalências de parasitas $(4,16 \%)$, intensidade $(1,25)$ e densidade relativa $(0,052)$, em N. devdevi. A infecção mais alta $(76,08 \%)$ foi constatada em adultos hospedeiros, ao passo que a taxa de infestação mais baixa (40\%) foi encontrada em amostras de peixes jovens. A prevalência de $73,68 \%$ foi verificada em hospedeiros do sexo feminino, enquanto a de $56,90 \%$, em indivíduos do sexo masculino. Maior infecção (83,33\%) foi observada durante a temporada de verão, e a menor infecção $(44,44 \%)$, durante o inverno. Da mesma forma, $71,79 \%$ dos peixes encontrados infectados foram coletados no trecho baixo do rio Swat, enquanto $52 \%$, no trecho alto.

Palavras-chave: intensidade, prevalência, parasitas helmintos, rio Swat.

\section{Introduction}

Schizothorax plagiostomus belongs to class actinopterygii, order cypriniformes and genus Schizothorax. It was named by Heckel 1838. Locally it is known as Swati fish in district Swat, KPK. It is found in cold water of snow- fed rivers and lakes all over the world. According to Bahuguna et al. (2009), Schozothorax plagiostomus is the most common fish, found in snow fed rivers, lakes and tributaries of Himalaya, Afghanistan, China, Pakistan, Nepal, Ladkha, Tibet, Bhutan and North-eastern part of India. Schizothorax plagiostomus is also used as a rich and delicious resource of food by the peoples of Himalayan area (Bahuguna et al., 2009).

Helminth parasites include Trematodes, Cestodes, Nematodes, and Acanthocephalans. These Helminth parasites harbor variety of fishes in the form of ecto and endo-parasites (Ahmad et al., 2014). Fish meat is a rich and cheaper source of proteins (Shafi et al., 2015). Peoples of underdeveloped and developing countries depend chiefly on fish meat for animal proteins and as a cheaper source of food (Dhar and Peerzada, 1989). Due to these valuable benefits, more attentiveness is being focus on fish inhabiting different kinds of water bodies throughout the globe (Becke et al., 2018). Fish of various rivers and lakes are infected by diverse nature of parasites, causing a variety of diseases in fish population (Boyd, 2003). Water pollution is the main cause of fish mortality in snow-fed and rain-fed rivers (Mishra et al., 2007; Ali et al., 2008; Dongdem et al., 2009; Buet et al., 2006).

These parasites impose great economics loss to fish populations. Alteration in environmental conditions is also a key source of wide range of diseases in fish fauna (Bagge and Valtonen, 1996; Shomorendra et al., 2005). Different kinds of helminthes parasites has been evaluated in the gills and intestines of Schizothorax plagiostomus in different regions of the globe (Bilqees et al., 2012; Shaikh et al., 2011; Moravec et al., 2010; Ahmed et al., 2007).

According to Ahmed et al. (2007); fish is used all over the world as a rich and cheaper source of white meat and proteins. Infection in fish body is a direct threat to its health and growth. Infection in fish is also an indirect threat to human morphology and physiology. So it is necessary that fish body must be maintained free of infections and all necessary measurement should be taken for doing so. Due to its white meat and rich source of proteins, fish is consumed all over the world, and fish farming is the leading source of income generation throughout the world. This paper describes the diversity of ecto and endo parasitic fauna infecting Schizothorax plagiostomus inhabitant of rivers of Swat, Pakistan and to initiate awareness among the public not to put their garbage into the river Swat, because it will led to water pollution, water pollution will led to fish infections and fish infestation will led to human infection.

\section{Material and Methods}

\subsection{Study area}

Swat district lies between $34^{\circ}-40$ to $35^{\circ} \mathrm{N}$ latitudes and $72^{\circ}$ to $74^{\circ}-6 \mathrm{E}$ longitudes. The total area of district swat is about $5337 \mathrm{Km}^{2}$ (2061square miles). This region is surrounded in the West by districts Chitral, Upper Dir and Lower Dir, in the North by Gilgat-Baltistan, in East and South East by Kohistan, Buner and Shangla. The origin of this river begins in Kohistan region of Kalam from Mahodand, Ushu and Gabral, which are the main tributaries of this river. The basis of this river lies in the Hindukush Mountains and is fed by the water from glaciers on peak of the mountains and flow throughout the year in a narrow gap from Kalam to Madyan and lower plains of the valley up to Chakdara. River Swat join the River Panjkora at Sharbatti (Busaq Bridge), District Malakand. Finally the River Swat empties into River Kabul near District Charsadda. The total length of River Swat from Kalam to River Kabul is about 240 kilometer Figure 1.

\subsection{Fish collection and processing}

Schizothorax plagiostomus were collected from three sampling sites like upper, middle and lower regions of River Swat by cast net, hand net and fishing rods. Some fish samples were also collected from local market. Local fishermen and experts help were also sought out for collection of S. plagiostomus from sampling area. Surgical gloves were put on hands during collection and handling of fishes as a precautionary measure to avoid inters mixing of parasites if present, especially for ectoparasites. After collection 5\% formalin were injected through mouth and anus into each fish sample. 


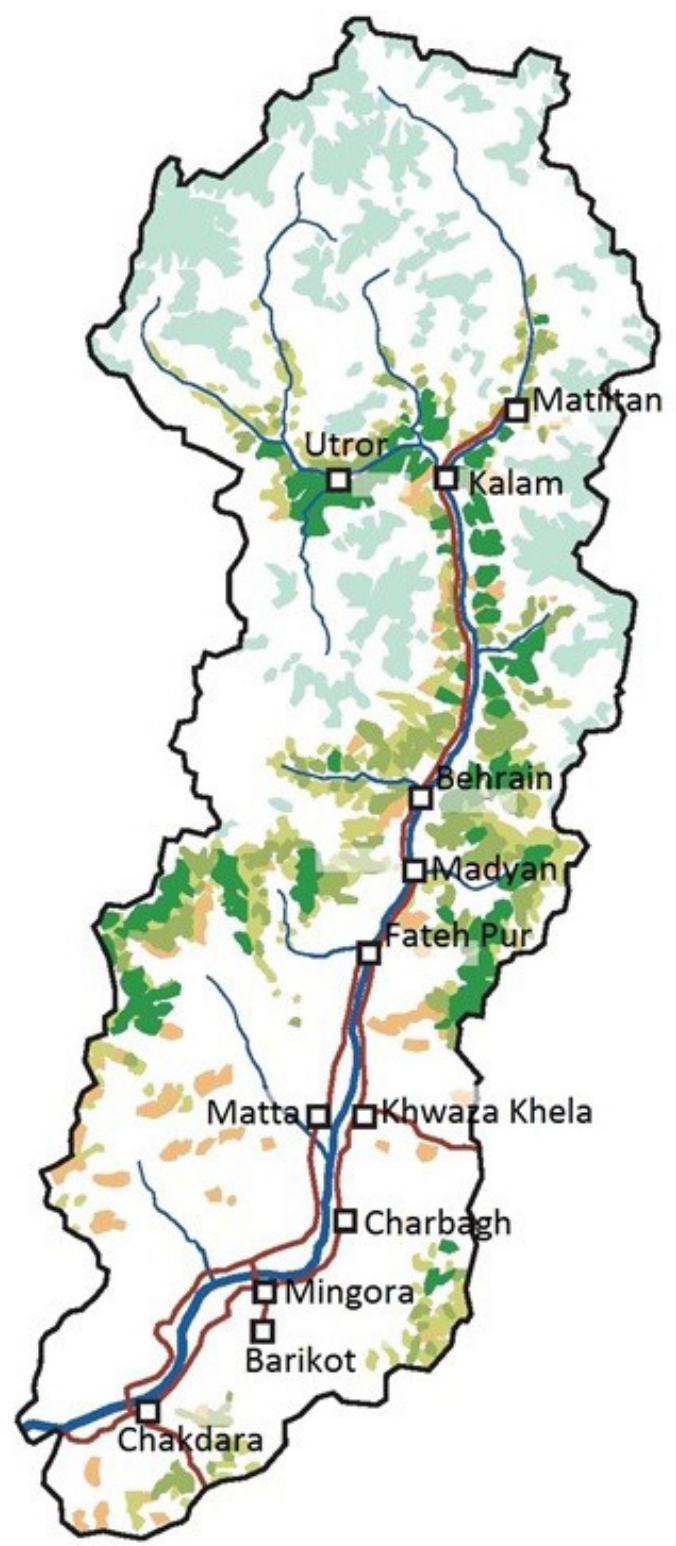

Figure 1. Map of river swat showing sampling area.

\subsection{Fish identification}

The collected fish samples were brought and identified in the lab of parasitology, department of Zoology, University of Malakand according to the standard keys described by Mirza and Sandhu (2007), Talwar and Jhingran (1992). Sexes of the collected host fish were also determined. The presence of tubercle on the head near snout indicate male individual. While if there is no tubercle on the snout region of fish then it will be a female individual. The abdomen of each fish specimen was pressed for the extrusion of whitish milt (for males) or eggs (for females). This strategy was used if the fish was in ripe or mature stage. The collected fish specimens were also dissected for sex identification. The presence of testes indicated male sex while the presence of ovary confirmed female sex. The standard length (SL) of each specimen was recorded from snout to the caudal peduncle with the help of china tape and steel scale while the body weight (BW) was noted with the help of precisa balance model No.18220 Switzerland.

\subsection{Parasite identification}

Each sample of fish in the lab was investigated for external parasites with the help of magnifying glass/binocular microscope. Eyes, nostril, mouth and fins were examined for the presence of parasites. Gills were removed through scissor and were placed in a Petri dish with the help of forceps. Attached parasites to the gills were transferred to the dish with the help of fine brush. For the collection and identification of endo-parasitic fauna, Schizothorax plagiostomus were dissected mid ventrally in the lab with the help of surgical dissecting box. The alimentary canal of each specimen was cut into different parts like fore gut, mid gut and hind gut. These parts were also shaken carefully to dislodge the parasites if it is lying attached to the epithelial lining by hooks and suckers. The epithelial lining of stomach and intestine was also scraped with the help of penknife to remove the parasites if it is still attached to the internal covering. The surfaces of other visceral organs, body cavities and membranes were also examined for encysted larva and parasites by hand lens. The identification of different helminthes parasites in the host fish were carried out with the help of keys described by Eiras et al. (2000), Martins et al. (2007), Tavares-Dias et al. (2001) and Yamaguti $(1961,1963)$.

\subsection{Statistical analysis}

The prevalence, mean intensity and relative density of infection was calculated by the formula given by Ayaz et al. (2011) as: Prevalence rate $(P R)=$ Number of host fish infected x 100 / number of host fish studied, Mean Intensity $(\mathrm{MI})=$ Total number of parasites recovered/ Total number of infected host examined, Relative Density $(\mathrm{RD})=$ Total number of parasites recovered / Total number of host examine. The relationship between the fish samples examined and that of infected was calculated by applying the GrapPad Prism Version 5. The value less than 0.05\% at $95 \%$ CI was considered significant.

\section{Result}

The present study of ecto and endo-parasitic fauna of Schizothorax plagiostomus of River Swat was carried out on monthly basis from July 2018 to February 2019. A total of 96 fishes of S. plagiostomus were collected from various localities and reaches of river swat and were examined for the presence of external and internal parasites. A total prevalence of $63.54 \%$ (61/96) was determined. From the collected 96 fishes of S. plagiostomus; Diplozoon paraddoxum, Rhabdochona shizothoracis, Rhabdochona species, Nippotaenia species and Neoechynorhynchus devdevi were collected. Overall prevalence of $63.54 \%$ was calculated for helminth parasites in S. plagiostomus. Highest parasite wise prevalence of $21.87 \%$ was recorded 
for $R$. shizothoracis, followed by D. paradoxum $19.79 \%$. While the lowest parasite wise prevalence of $4.16 \%$ was recorded for Nippotaenia species. Total intensity of 2.90 of helminth parasites was collected during the present work, while highest intensity of 4.09 was investigated for $R$. schizothoracis and lowest intensity of 1.25 was calculated for Nippotaenia species. Similarly overall relative density of 1.84 was recorded for helminth parasites. The highest relative density of 0.895 was calculated for $R$. schizothoracis, followed by D. paradaxum, while lowest relative density of 0.052 was investigated for Nippotaenia. species (Table 1).

High prevalence of parasites was recorded in months of July and August $83.33 \%$, followed by month of October $75 \%$, September and November 66.66\% (each), December $58.33 \%$, January $41.66 \%$ and lowest was recorded in February $33.33 \%$. This difference in prevalence of helminth parasites in different months was observed due to seasonal variations and environmental conditions of River Swat Table 2.

A strong correlation was observed between length and weight of S. plagiostomus and degree of infection. Prevalence, intensity and relative density of helminth parasites increases with increase in the length and weight of host fish. This data show that prevalence, intensity and relative density of helminth parasites is higher $76.08 \%$, 2.97 and 2.26 respectively in adults' hosts and lowest $40 \%$, 2.0 and 0.8 in younger host fish (Table 3 ).

The total prevalence of $56.89 \%$, intensity 2.21 and relative density 1.25 were recorded for male individuals, and prevalence of $73.68 \%$, intensity 3.71 and relative intensity 2.73 was recorded respectively for helminth parasites in female individuals. In this way high rate of infection were observed in female individuals than male individuals (Table 4).

Highest rate of prevalence $83.33 \%$, intensity 3.3 and relative density 2.75 was recorded during the summer season while lowest rate of prevalence $44.44 \%$, intensity 2.68 and relative density 1.19 was recorded during the winter season (Table 5).

According to localities wise collection of the host, Fish samples collected from lower reaches have highest prevalence, intensity and relative density of $71.79 \%$, 3.25 and 2.33 respectively than the prevalence, intensity and relative density of upper reaches $52 \%, 2.23$ and 1.16 (Table 6).

Table 1. Overall and Parasites Wise Prevalence, intensity and relative density of Helminth Parasites in S. Plagiostomus of River Swat.

\begin{tabular}{|c|c|c|c|c|c|c|}
\hline Name of the parasite & $\begin{array}{c}\text { Host } \\
\text { examined }\end{array}$ & $\begin{array}{c}\text { Hosts } \\
\text { infected }\end{array}$ & $\begin{array}{c}\text { Prevalence } \\
\%\end{array}$ & $\begin{array}{l}\text { Parasites } \\
\text { observed }\end{array}$ & Intensity & $\begin{array}{r}\text { Relative } \\
\text { density }\end{array}$ \\
\hline Diplozoon paradoxum & 96 & 19 & 19.79 & 55 & 2.89 & 0.572 \\
\hline Rhabdochona schizothoracis & & 21 & 21.87 & 86 & 4.09 & 0.895 \\
\hline Rhabdochona species & & 11 & 11.45 & 21 & 1.91 & 0.218 \\
\hline Nippotaenia species & & 04 & 4.16 & 05 & 1.25 & 0.052 \\
\hline Neoechinorhynchus devdevi & & 06 & 6.25 & 10 & 1.67 & 0.104 \\
\hline Total & & 61 & 63.54 & 177 & 2.90 & 1.84 \\
\hline
\end{tabular}

Statistical Analysis: $\mathrm{P}=0.000195 \% \mathrm{CI}=--74.37$ to -93.23 .

Table 2. Monthly Prevalence of Helminth Parasites Found in S. plagiostomus (Snow Trout) of River Swat from July, 2018 to February, 2019.

\begin{tabular}{lccc}
\hline \multicolumn{1}{c}{ Name of the month } & Hosts examined & Hosts infected & Prevalence \% \\
\hline July 2018 & 12 & 10 & 83.33 \\
August 2018 & 12 & 10 & 83.33 \\
September 2018 & 12 & 08 & 66.66 \\
October 2018 & 12 & 09 & 75.00 \\
November 2018 & 12 & 08 & 66.66 \\
December 2018 & 12 & 07 & 58.33 \\
January 2019 & 12 & 05 & 41.66 \\
February 2019 & 12 & 04 & 33.33 \\
\hline
\end{tabular}

Statistical Analysis: $\mathrm{P}=0.000895 \% \mathrm{CI}=2.536$ to 6.214 .

Table 3. Length and Weight Wise Prevalence, Intensity and Relative Density of Helminth Parasites in S. Plagiostomus of River Swat.

\begin{tabular}{cccccccc}
\hline $\begin{array}{c}\text { Length in } \\
\text { cm }\end{array}$ & $\begin{array}{c}\text { Weight in } \\
\text { grams }\end{array}$ & $\begin{array}{c}\text { Host } \\
\text { observed }\end{array}$ & $\begin{array}{c}\text { Host } \\
\text { infected }\end{array}$ & $\begin{array}{c}\text { Parasites } \\
\text { collected }\end{array}$ & $\begin{array}{c}\text { Prevalence } \\
\%\end{array}$ & Intensity & $\begin{array}{c}\text { Relative } \\
\text { density }\end{array}$ \\
\hline $10-20$ & $100-150$ & 15 & 06 & 12 & $40 \%$ & 02 & 0.8 \\
$20.1-30$ & $151-300$ & 35 & 20 & 51 & $57.14 \%$ & 2.55 & 1.45 \\
$30.1-45$ & $301-800$ & 46 & 35 & 104 & $76.08 \%$ & 2.97 & 2.26 \\
\hline
\end{tabular}


Table 4. Sex Wise Prevalence, Intensity and Relative Density of Helminth Parasites in S. Plagiostomus of River Swat, Khyber Pakhtunkhwa.

\begin{tabular}{ccccccc}
\hline Sex of host & $\begin{array}{c}\text { Host } \\
\text { examined }\end{array}$ & Host infected & $\begin{array}{c}\text { Parasites } \\
\text { collected }\end{array}$ & Prevalence & Intensity & $\begin{array}{c}\text { Relative } \\
\text { density }\end{array}$ \\
\hline Male & 58 & 33 & 73 & $56.90 \%$ & 2.21 & 1.25 \\
Female & 38 & 28 & 104 & $73.68 \%$ & 3.71 & 2.73 \\
\hline
\end{tabular}

Statistical Analysis: $\mathrm{P}=0.115895 \% \mathrm{CI}=-26.85$ to 61.85 .

Table 5. Seasons Wise Prevalence, Intensity and Relative Density of Helminth Parasites in S. Plagiostomus of River Swat, KP Pakistan.

\begin{tabular}{cccccccc}
\hline \multicolumn{2}{c}{ Seasons } & $\begin{array}{c}\text { Host } \\
\text { examined }\end{array}$ & $\begin{array}{c}\text { Host } \\
\text { infected }\end{array}$ & $\begin{array}{c}\text { parasites } \\
\text { recovered }\end{array}$ & Prevalence & Intensity & $\begin{array}{c}\text { Relative } \\
\text { Density }\end{array}$ \\
\hline Summer & $\begin{array}{c}\text { July } \\
\text { August }\end{array}$ & 24 & 20 & 66 & 83.33 & 3.3 & 2.75 \\
Wutumn & $\begin{array}{c}\text { September } \\
\text { October } \\
\text { November }\end{array}$ & 36 & 25 & 68 & 69.44 & 2.72 & 1.88 \\
$\begin{array}{c}\text { December } \\
\text { January } \\
\text { February }\end{array}$ & 36 & 16 & 43 & 44.44 & 2.68 & 1.19 \\
\hline
\end{tabular}

Statistical Analysis: $\mathrm{P}=0.035495 \% \mathrm{CI}=-1.522$ to 24.92 .

Table 6. Locality wise prevalence (\%), intensity and relative density in S. plagiostomus of River Swat, KP, Pakistan

\begin{tabular}{ccccccc}
\hline Factor & $\begin{array}{c}\text { Fish } \\
\text { examined }\end{array}$ & Fish infected & $\begin{array}{c}\text { Prevalence } \\
(\mathbf{\%})\end{array}$ & $\begin{array}{c}\text { parasites } \\
\text { recovered }\end{array}$ & Intensity & $\begin{array}{c}\text { Relative } \\
\text { density }\end{array}$ \\
\hline Upper reaches & 25 & 13 & 52 & 29 & 2.23 & 1.16 \\
Middle reaches & 32 & 20 & 62.5 & 57 & 2.85 & 1.78 \\
Lower reaches & 39 & 28 & 71.79 & 91 & 3.25 & 2.33 \\
\hline
\end{tabular}

Statistical Analysis: $\mathrm{P}=0.00895 \% \mathrm{CI}=10.23$ to 13.10 .

\section{Discussion}

In this research study a total of 96 host fish specimen were collected from different sites of River Swat. All the collected specimens of host fish were examined for the presence of ecto and endo-helminth parasites. After examination 61 out of 96 were found infected and total prevalence of $63.54 \%$ was calculated. Khan and Bilqees (1990); conducted a similar research study on helminth parasitic of fresh water fishes and calculated high prevalence rate for most of the helminth parasites. According to them some Cestodes have low prevalence rate but it is due to incomplete life cycle of these Cestodes and further transmission comes to an end. High prevalence rate $88.33 \%$ of helminth parasites was obtained during the moths of July and August while lowest prevalence rate of $41.66 \%$ and $33.33 \%$ was recorded during the months of January and February respectively. Ahmad et al. (2014); conducted a similar study on the prevalence of helminth parasites in 115 fish samples of S. plagiostomus from river swat and observed similar finding. They calculated high prevalence rate during winter season which is in contradiction with the present study. Similar finding were observed by Ahmad et al. (2014) and Aydoğdu et al. (2011).

The parasites wise prevalence of five helminth parasites in host fish were calculated according to following order. High prevalence of $R$. schizothoracis $21.88 \%$ was recorded followed by D paradoxum $19.79 \%$, Rhabdochona species $11.45 \%$, and $N$. devdevi $6.25 \%$ while the lowest value of $4.16 \%$ was recorded for Nippotaenia species. Ahmad et al. (2014); collected about 9 species of helminth parasites from 107 infected samples of S. plagiostomus and highest infection rate was noted for $R$. schizothoracis and $D$. paradoxum which is parallel with the finding of present study.

The overall intensity of 2.90 was calculated for helminth parasites. Highest parasite wise intensity of 4.09 was observed for $R$. schizothoracis, followed by $D$. paradoxum 2.89, Rhabdochona Species 1.91 and N. devdevi 1.67, while the lowest intensity of 1.25 was recorded for Nippotaenia species. A similar research study was conducted by Parween and Rahman (2000); maximum infection rate of $22.73 \%$ was noted in August and the lowest in February 4.55\%. In their host fish, Channa punctatus, maximum infestation rate of $18.29 \%$ was documented in September and the lowest $6.86 \%$ in the month of March.

The overall relative density of 1.84 was observed for helminth parasites in $S$. plagiostomus. Highest value of relative density of 0.895 was observed for $R$. schizothoracis followed by $D$. paradoxum, 0.572 , Rhabdochona species 0.218 and $N$. devdevi 0.104 . While lowest relative density of 0.052 was observed for Nippotaenia species. The finding of Khurshid and Ahmad (2014), Leela and Rao (2014); are in accordance with the data observed in present study. 
Highest infection rate of $76.08 \%$ was observed as the host fish grew in length and weight (Adult Host). While lowest prevalence rate of $40 \%$ was observed in young hosts. According to Omeji et al. (2014); with increase in weight and length of host fish, the prevalence of parasitic infection also increases. Present finding about length and weight of host fish is in accordance with the finding calculated by Bichi and Yelwa (2010); in fresh water fishes of Nigeria.

Female fish were found highly infected $73.68 \%$ than male $56.90 \%$. The data collected during the present research agreed with the data collected about host gender by Amare et al. (2014). Similarly Omeji et al. (2014); also confirmed that female fish were highly infected with $57.5 \%$ infection rate and male are less infected with $42.4 \%$ infection rate.

The prevalence of infection during summer was $83.33 \%$, $69.44 \%$ during autumn season, while $44.44 \%$ infection rate was observed during the winter season. Similarly Khurshed and Ahmad, 2014; studied S. labiatus, and observed highest prevalence in summer $39.5 \%$, followed by autumn $19 \%$ and least prevalence rate $3.8 \%$, was calculated in winter respectively.

Fish samples collected from lower reaches have highest prevalence $71.79 \%$, intensity 3.25 and relative density of 2.33 than the prevalence $52 \%$, intensity 2.23 and relative density of 1.16 of fishes collected from upper reaches. Similar finding were observed by Crisp et al. (2001).

\section{References}

AHMAD, R., AYAZ, S., SHAMS, S. and AHMAD, R., 2014. Prevalence and morphology of helminth parasites of fish from river Swat, Khyber Pakhtunkhwa. Pakistan Journal of Agricultural Research, vol. 27, no. 2, pp. 142-148.

AHMED, M. S., IQBAL, T., MAHMOOD, A., GULZARIN, M., and ABID, M., 2007. Helminth parasites of some freshwater fishes. Punjab University Journal Zoology, vol. 22, no. 1-2, pp. 1-6.

ALI, D., NAGPURE, N.S., KUMAR, S., KUMAR, R. and KUSHWAHA, B., 2008. Genotoxicity assessment of acute exposure of chlorpyrifos to freshwater fish Channa punctatus (Bloch) using micronucleus assay and alkaline single-cell gel electrophoresis. Chemosphere, vol. 71, no. 10, pp. 1823-1831. http:// dx.doi.org/10.1016/j.chemosphere.2008.02.007. PMid:18359502.

AMAre, A., AlemayehU, A. and AYlate, A., 2014. Prevalence of internal parasitic helminthes infected Oreochromis niloticus (Nile Tilapia), Clarias gariepinus (African Catfish) and Cyprinus carpio (Common Carp) in Lake Lugo (Hayke), Northeast Ethiopia. Journal of Aquaculture Research \& Development, vol. 5 , no. 3, pp. 1-5.

AYDOĞDU, A., EMRE, Y., EMRE, N. and ALTUNEL, F.N., 2011. The occurrence of helminth parasites (Nemathelminthes) in some freshwater fish from streams discharging into Antalya Bay in Antalya, Turkey: two new host records from Antalya. Turkish Journal of Zoology, vol. 35, no. 6, pp. 859-864.

BAGGE, A.M. and VALTONEN, E.T., 1996. Experimental study on the influence of paper and pulp mill effluent on the gill parasite communities of roach (Rutilus rutilus). Parasitology, vol. 112, no. 5, pp. 499-508. http://dx.doi.org/10.1017/S0031182000076964.
BAHUGUNA, S.N., NEGI, R.S. and UPADHYAY, M.K., 2009. Ex-situ study on density dependent survival after handling yolk sac larvae of snow trout, Schizothorax plagiostomus Heckel. Our Nature, vol. 7, no. 1, pp. 146-150. http://dx.doi.org/10.3126/ on.v7i1.2562.

BECKE, C., SCHUMANN, M., STEINHAGEN, D., GEIST, J. and BRINKER, A., 2018. Physiological consequences of chronic exposure of rainbow trout (Oncorhynchus mykiss) to suspended solid load in recirculating aquaculture systems. Aquaculture, vol. 484, pp. 228-241. http://dx.doi.org/10.1016/j. aquaculture.2017.11.030.

BICHI, A. and YELWA, S., 2010. Incidence of piscine parasites on the gills and gastrointestinal tract of clarias gariepinus (teugels) at bagauda fish farm, Kkano. Bayero Journal of Pure and Applied Sciences, vol. 3, no. 1, pp. 104-107. http://dx.doi.org/10.4314/ bajopas.v3i1.58732.

BILQEES, F.M., HADI, R., KHAN, A. and PERVEEN, S., 2012. Description of a new subfamily Heckmanninae (Monorchiidae (Odhner, 1911) Nicoll, 1915) with a new genus and species from a freshwater fish of Sindh, Pakistan. Pakistan Journal of Zoology, vol. 44 , no. 3 , pp. 723-726.

BOYD, C.E., 2003. Guidelines for aquaculture effluent management at the farm-level. Aquaculture, vol. 226, no. 1-4, pp. 101-112. http://dx.doi.org/10.1016/S0044-8486(03)00471-X.

BUET, A., BANAS, D., VOllaiRE, Y., COULET, E. and ROCHE, H., 2006. Biomarker responses in European eel (Anguilla anguilla) exposed to persistent organic pollutants. A field study in the Vaccarès lagoon (Camargue, France). Chemosphere, vol. 65 , no. 10, pp. 1846-1858. http://dx.doi.org/10.1016/j. chemosphere.2006.03.074. PMid:16714045.

CRISP, M.D., LAFFAN, S., LINDER, H.P. and MONRO, A., 2001. Endemism in the Australian flora. Journal of Biogeography, vol. 28 , no. 2 , pp. 183-198. http://dx.doi.org/10.1046/j.13652699.2001.00524.x.

DHAR, R.L. and PEERZADA, M.Y., 1989. Seasonal variation in the helminth parasites of common snow trout $S$. niger in Wu-lar lake. National Symposium on Research Advances in Parasitology, pp. 1-15.

DONGDEM, J.T., SOYIRI, I. and OCLOO, A., 2009. Public health significance of viral contamination of drinking water. African Journal of Microbiological Research, vol. 3, no. 12, pp. 856-861.

EIRAS, J.D.C., TAKEMOTO, R.M. and PAVANELLI, G.C., 2000. Métodos de estudo e técnicas laboratoriais em parasitologia de peixes. Maringá: Eduem, $171 \mathrm{p}$.

KHAN, A. and BILQEES, P.M., 1990. Allocreadium kalriai, new species (Trematoda: Allocreadiidae) from the fish Channa striatus (BI) of Kalri lake, Sind. Pakistan Journal of Zoology, vol. 22, pp. 345-351.

KHURSHID, I. and AHMAD, F., 2014. Population dynamics of parasites as an evaluation metric to assess the trophic quality of fresh water bodies: A case study showing relationship of infection level of helminths in Schizothorax spp. of River Sindh, Kashmir. International Journal of Fisheries and Aquatic Studies, vol. 2, no. 2, pp. 206-209.

LEELA, B. and RAO, K.R., 2014. Nematode parasites in a freshwater fish glossogobius giuris (Hamilton-Buchanan, 1822) at Lower Manair Dam, KarimnagarDt. Andhra Pradesh, India. IOSR Journal of Pharmacy and Biological Sciences. vol. 9, no. 2, pp. 37-40. 
MARTINS, M.L., GHIRALDELLI, L., GARCIA, F., ONAKA, E.M. and FUJIMOTO, R.Y., 2007. Experimental infection in Notodiaptomus sp. (Crustacea: Calanoida) with larvae of Camallanus sp.(Nematoda: Camallanidae). Arquivo Brasileiro de Medicina Veterinária e Zootecnia, vol. 59, no. 2, pp. 382-386. http://dx.doi.org/10.1590/S0102-09352007000200018.

MIRZA, M.R. and SANDHU, A.A., 2007. Fishes of the Punjab Pakistan. Lahore: Polymer Publication, Urdu Bazar.

MISHRA, S., BHALKE, S., SARADHI, I.V., SUSEELA, B., TRIPATHI, R.M., PANDIT, G.G. and PURANIK, V.D., 2007. Trace metals and organometals in selected marine species and preliminary risk assessment to human beings in Thane Creek area, Mumbai. Chemosphere, vol. 69, no. 6, pp. 972-978. http:// dx.doi.org/10.1016/j.chemosphere.2007.05.013. PMid:17604811.

MORAVEC, F., SCHOLZ, T., ASH, A. and KAR, P.K., 2010. New data on the morphology and taxonomy of three species of Rhabdochona (Nematoda: Rhabdochonidae) parasitizing fishes in India. Folia Parasitologica, vol. 57, no. 4, pp. 295-306. http:// dx.doi.org/10.14411/fp.2010.036. PMid:21344842.

OMEJI, S., TIAMIYU, L.O., ANNUNE, P.A. and SOLOMON, S.G., 2014. Ecto and intestinal parasites of Malapterurus electricus from upper river benue. Journal of Global Biosciences, vol. 3, pp. 895-903.

PARWEEN, S. and RAHMAN, M.R., 2000. Distribution of helminth parasites in different organs and their monthly rate of infection in three freshwater fishes of Rajshahi. University Journal of Zoology, vol. 19, pp. 67-72.

SHAFI, N., AYUB, J. and AKHTAR, T., 2015. Physico-chemical variables and fish parasites of River Neelum Azad Jammu and Kashmir, Pakistan. Journal of Bioresource Management, vol. 2, no. 2, pp. 10. http://dx.doi.org/10.35691/JBM.5102.0024.

SHAIKH, G.S., KHAN, A. and BILQEES, F.M., 2011. A new trematode of the genus Genarchopsis Ozaki, 1925 from freshwater fish of Sindh, Pakistan. Pakistan Journal of Zoology, vol. 43, no. 5

SHOMORENDRA, M., JHA, A. and KUMAR, P., 2005. Seasonal occurrence of helminth parasites in fishes of Loktaklake, Manipur. Uttar Pradesh Journal of Zoology, vol. 25, no. 1, pp. 23-27.

TALWAR, P.K. and JHINGRAN, A.G., 1992. Inland fishes of India. Records Indian Journal, vol. 3, no. 2, pp. 19-24.

TAVARES-DIAS, M., MORAES, F.R.D., MARTINS, M.L., and KRONKA, S.N., 2001. Parasitary fauna of fish from the fishing village of Franca, São Paulo, Brazil. II. Metazoans. Brazilian Journal of Zoology, vol. 18, suppl. 1, pp. 81-95.

YAMAGUTI, S., 1961. Systema helminthum. Volume III. The nematodes of vertebrates. New York: Interscience Publishers, $1261 \mathrm{p}$.

YAMAGUTI, S., 1963. Systema helminthum. VolumeIV. Monogenea and Aspido-cotylea. New York: Interscience Publishers, 699 p. 